\title{
Optimum Efficiency of Photogalvanic Cell for Solar Energy Conversion: Lissamine Green B-Ascorbic Acid-NaLS System
}

\author{
Kishna Ram Genwa, Kewal Singh \\ Department of Chemistry, Jai Narain Vyas University, Jodhpur, India. \\ Email: krg2004@rediffmail.com \\ Received January $12^{\text {th }}, 2013$; revised February $28^{\text {th }}, 2013$; accepted March $4^{\text {th }}, 2013$ \\ Copyright (C) 2013 Kishna Ram Genwa, Kewal Singh. This is an open access article distributed under the Creative Commons Attribution \\ License, which permits unrestricted use, distribution, and reproduction in any medium, provided the original work is properly cited.
}

\begin{abstract}
Photogalvanic cells are photoelectrochemical cells chargeable in light for solar energy conversion and storage. They may be energy source for the future, if their electrical performance is increased. In this study, a photosensitizer Lissamine green B, a reductant Ascorbic acid and a surfactant NaLS have been used in the photogalvanic cell. The generated photopotential and photocurrent are $850.0 \mathrm{mV}$ and $375.0 \mu \mathrm{A}$ respectively. The conversion efficiency of the cell, fill factor and the cell performance were observed $1.0257 \%, 0.2598 \%$ and 170.0 minutes in dark respectively. The effects of different parameters on the electrical output of the photogalvanic cell were observed. A mechanism was proposed for the photogeneration of electrical energy.
\end{abstract}

Keywords: Lissamine Green B; Ascorbic Acid; Sodium Lauryl Sulphate (NaLS); Photopotential; Photocurrent; Fill Factor; Conversion Efficiency

\section{Introduction}

World population in doubling about every thirty five years, though the rate of growth is very different in different countries. The world energy use is doubling every fourteen years and the need is increasing faster still. One of the main energy sources is oil and the rate of production is expected to peak in the next few years. There are still plentiful supplies of coal, the other principal energy source, but it is even more seriously polluting than oil, leading to acid rain and climate change. This combination of increasing need and diminishing supply constitutes the energy crisis. The world urgently needs a clean energy source that is able to meet world energy needs. This is without doubt the most serious problem facing mankind [1].

Becquerel [2] first observed the flow of current between the unsymmetrical illuminated metal electrodes in sunlight. The photogalvanic cell works on photogalvanic effect. This effect was reported by Rideal and Williams [3] but it was systematically investigated by Rabinowitch [4,5]. Fox and Kabir-ud-din [6] studied photogalvanic effect in carbanionic photogalvanic cell. Murthy et al. [7] have studied photogalvanic effect in dye-sensitizing photogalvanic cells. Rohatgi-Mukherjee et al. [8] studied photogalvanic effect in Phenosafranine Dye-EDTA sandwich cell. Ameta et al. [9] have studied the use of micelles in photogalvanic cell for solar energy conversion and storage. Gangotri et al. [10,11] have increased the electrical output as well as storage capacity up to reasonable mark by using various photosensitizer with micelles in photogalvanic cell. Some more phenothiazine dyes like Azur-B, toludine blue, and methylene blue etc. as sensitizers in photogalvanic cells for solar energy conversion and storage have been used by Gangotri and Lal [12,13], Gangotri and Genwa [14] and Gangotri and Meena [15]. Studies on photogalvanic cell containing Azur B-NTA-CPC system for solar energy conversion and storage reported by Genwa and Gangotri [16]. Role of Rodamine B in photocurrent generation using anionic surfactant in liquid phase photoelectrochemical cell for solar energy conversion and storage was reported by Genwa and Kumar [17]. Genwa and Chouhan [18] have recently developed some photogalvanic systems for solar energy conversion and storage. They have used different micelles species, photosensitizers, and reductants in photogalvanic cells but no attention has been paid to the use of the Lissamine green B-Ascorbic acid-NaLS system to enhance the electrical output and performance of 
the photogalvanic cells with a focus on reducing the cost of the cells to gain commercial viability. Therefore, the present work was undertaken.

\section{Materials and Method}

Lissamine green B (Scheme 1, Loba Chemie, Mumbai), Ascorbic acid (Ases Chemical, Jodhpur), NaLS (Sisco Research Laboratories, Mumbai) and Sodium hydroxide (RFCL, New Delhi) were used in the present work.

All the stock solutions were prepared in doubly distilled water (conductivity $3.5 \times 10^{-5} \mathrm{Sm}^{-1}$ ). The stock solutions of all the chemicals were prepared by direct weighing and kept in amber colored containers to protect from light. In the present work we used the different solutions of various concentrations. The concentration of solutions of Lissamine green $\mathrm{B}$, Ascorbic acid and NaLS and $\mathrm{NaOH}$ were $2.8 \times 10^{-5} \mathrm{M}, 1.4 \times 10^{-3} \mathrm{M}, 1.6 \times 10^{-3} \mathrm{M}$ and $1.0 \mathrm{~N}$ respectively. Absorption spectra were recorded by using Spectrophotometer (Systronics 106) with the matched pair of silica cuvetts (path length $1 \mathrm{~cm}$ ). All spectral measurements were duplicated in a constant temperature water bath maintained within $\pm 0.1^{\circ} \mathrm{C}$ and mean values were processed for data analysis. Photogalvanic effect of dye was studied in a $\mathrm{H}$-shaped glass tube which consist of known amount of the solutions of Lissamine green $\mathrm{B}$, Ascorbic acid, $\mathrm{NaLS}, \mathrm{NaOH}$ and double distilled water so as to kept the total volume of the mixture always $25.0 \mathrm{ml}$. A platinum electrode $\left(1.0 \times 1.0 \mathrm{~cm}^{2}\right)$ dipped in one limb and a saturated calomel electrode (SCE) immersed in another limb of the H-tube. The terminals of the electrodes were connected to a digital $\mathrm{pH}$ meter and the whole cell was placed in the dark. The photopotential was measured in dark when the cell attains a stable potential and after then the limb containing platinum electrode was exposed to $200 \mathrm{~W}$ tungsten lamp (philips). The light intensity was varied by employing tungsten lamps of different wattage. A water filter was placed between the illuminated chamber and the light source to cut-off thermal radiations. Photopotential and photocurrent developed by the system were measured by digital $\mathrm{pH}$ meter (Systronics model 335) and digital ammeter (Nucon). The intensity of light was measured in terms of $\mathrm{mW} \cdot \mathrm{cm}^{-2}$ with the help of solar intensity meter<smiles>CN(C)c1ccc(C(=C2C=CC(=[N+](C)C)C=C2)c2c(O)c(S(=O)(=O)[O-])cc3cc(S(=O)(=O)O[Al])ccc23)cc1</smiles>

Scheme 1. Lissamine green $B$.
(Solarimeter model-501).

The current voltage characteristics were studied by applying an external load with the help of a carbon pot $(\log 470 \mathrm{~K})$ connected in the circuit. Over all experimental set up is shown in Figure 1.

\section{Result and Discussion}

\subsection{Absorption Properties of Photosensitizes and Surfactan}

It was observed that the photosensitizer shows absorption peak $\left(\lambda_{\max }\right)$ in visible region with maximum at $635 \mathrm{~nm}$. Absorption spectrum of photosensitizer after adding known concentration of surfactant solution was also taken. The concentration of Lissamine green $\mathrm{B}$ and NaLS solution for the experiment were kept at $\left(2.8 \times 10^{-5} \mathrm{M}\right)$ and NaLS $\left(1.6 \times 10^{-3} \mathrm{M}\right)$ respectively. The changes in the spectra are shown in Figure 2.

\subsection{Effect of Variation of Lissamine Green B, Ascorbic Acid and NaLS Concentration}

The results showing the effect of variation of Lissamine

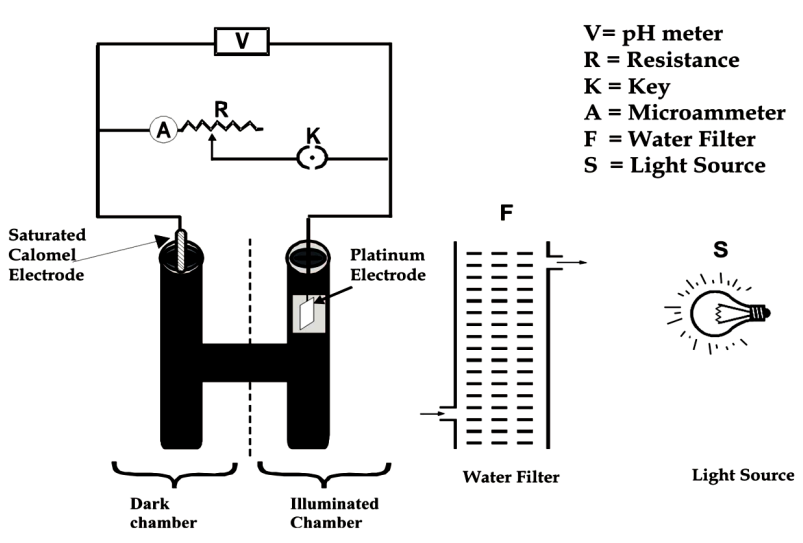

Figure 1. Photogalvanic setup.

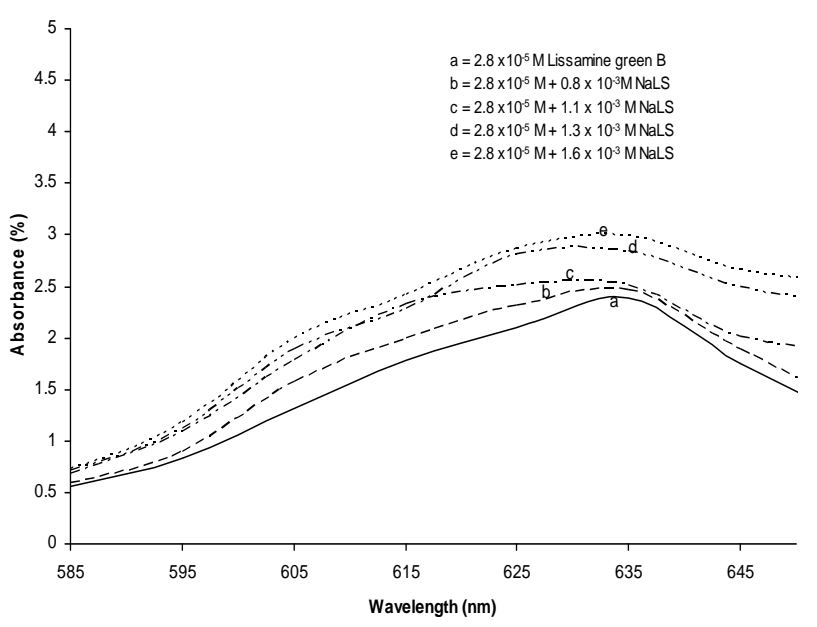

Figure 2. Absorption spectra of lissamine green B. 
green B, Ascorbic acid and NaLS concentration are summarized in Table 1. Variation of dye concentration studied by using solution of Lissamine green B of different concentrations. It was observed that the photopotential and photocurrent increased with increase in concentration of the dye [Lissamine green B]. A maxima (at $850.0 \mathrm{mV}$ and $375.0 \mu \mathrm{A}$ ) was obtained for a particular value of dye concentration $\left(2.8 \times 10^{-5} \mathrm{M}\right)$, above which a decrease in electrical output of the cell was observed. Low electrical output observed at the lower concentration range of dye due to limited number of dye molecules to absorb the major portion of the light in the path, while higher concentration of dye again resulted in a decrease in electrical output because intensity of light reaching the molecule near the electrode decrease due to absorption of the major portion of the light by the dye molecules present in the path, therefore corresponding fall in the electric output of the cell.

Reductant concentration also affects the cell output. With the increase in concentration of the reductant [Ascorbic acid], the photopotential and photocurent was found to increase till it reaches a maximum value at $1.4 \times$ $10^{-3} \mathrm{M}$. These values are $850.0 \mathrm{mV}$ and $375.0 \mu \mathrm{A}$ re-

Table 1. Effect of variation of Lissamine green B, Ascorbic acid and NaLS concentrations.

\begin{tabular}{|c|c|c|}
\hline Concentrations & Photopotential (mV) & Photocurrent $(\mu \mathrm{A})$ \\
\hline \multicolumn{3}{|c|}{ [Lissamine green $\mathrm{B}] \times 10^{-5} \mathrm{M}$} \\
\hline 2.2 & 775.0 & 285.0 \\
\hline 2.5 & 805.0 & 328.0 \\
\hline 2.8 & 850.0 & 375.0 \\
\hline 3.2 & 812.0 & 342.0 \\
\hline 3.5 & 728.0 & 288.0 \\
\hline \multicolumn{3}{|c|}{ [Ascorbic acid] $\times 10^{-3} \mathrm{M}$} \\
\hline 1.0 & 745.0 & 276.0 \\
\hline 1.2 & 805.0 & 322.0 \\
\hline 1.4 & 850.0 & 375.0 \\
\hline 1.6 & 812.0 & 338.0 \\
\hline 1.8 & 735.0 & 282.0 \\
\hline \multicolumn{3}{|c|}{$[\mathrm{NaLS}] \times 10^{-3} \mathrm{M}$} \\
\hline 1.1 & 742.0 & 298.0 \\
\hline 1.3 & 798.0 & 332.0 \\
\hline 1.6 & 850.0 & 375.0 \\
\hline 1.9 & 772.0 & 332.0 \\
\hline 2.2 & 712.0 & 295.0 \\
\hline
\end{tabular}

Light Intensity $=10.4 \mathrm{~mW} \cdot \mathrm{cm}^{-2} ;$ Temperature $=303 \mathrm{~K}$. specttively. On further increase in concentration of Ascorbic acid, a decrease in the electrical output of the cell was observed. The fall in power output was also resulted with decrease in concentration of reductant due to less number of molecules available for electron donation to the cationic form of dye. On the other hand, the movement of dye molecules hindered by the higher concentration of reductant to reach the electrode in the desired time limit and it will also result in to a decrease in electrical output.

The electrical output of the cell was increased on increasing the concentration of surfactant [NaLS]. A maximum $(850.0 \mathrm{mV}$ and $375.0 \mu \mathrm{A})$ result was obtained at a certain value $\left(1.6 \times 10^{-3} \mathrm{M}\right)$ of concentration of NaLS. On further increasing the surfactant concentration it react as a barrier and major portion of the surfactant photobleach the less number of dye molecules so that a down fall in electrical output was observed.

\subsection{Effect of $\mathbf{p H}$}

Photogalvanic cell containing Lissamine green B-Ascorbic acid-NaLS system was found to be quite sensitive to $\mathrm{pH}$ of the solution. It was observed that the increase in photopotential and photocurrent of the cell with increase in $\mathrm{pH}$ value (in alkaline range). At $\mathrm{pH} 12.58$ a maxima $(850.0 \mathrm{mV}$ and $375.0 \mu \mathrm{A})$ was achieved. On further increase in $\mathrm{pH}$, there was a decrease photopotential and photocurrent. The optimum electrical output was obtained at particular $\mathrm{pH}$ value. It may be due to better availability of reductant's donor form at that $\mathrm{pH}$ value. The results showing the effect of $\mathrm{pH}$ are summarized in Table 2.

\subsection{Effect of Diffusion Length and Electrode Area}

Effect of variation of diffusion length (distance between the two electrodes) on the current parameter of the cell $\left(i_{\max }\right)$ was studied by using $\mathrm{H}$-shaped cells of different

Table 2. Effect of pH.

\begin{tabular}{ccc}
\hline $\mathrm{pH}$ & Photopotential $(\mathrm{mV})$ & Photocurrent $(\mu \mathrm{A})$ \\
\hline 12.20 & 718.0 & 276.0 \\
12.40 & 782.0 & 334.0 \\
12.58 & 850.0 & 375.0 \\
12.76 & 766.0 & 318.0 \\
12.96 & 712.0 & 282.0 \\
\hline
\end{tabular}

[Lissamine green B] $=2.8 \times 10^{-5} \mathrm{M}$; Light Intensity $=10.4 \mathrm{~mW} \cdot \mathrm{cm}^{-2}$;

[Ascorbic acid] $=1.4 \times 10^{-3} \mathrm{M}$; Temperature $=303 \mathrm{~K} ;[\mathrm{NaLS}]$

$=1.6 \times 10^{-3} \mathrm{M}$. 
dimensions. It was observed that in the first few minutes of illuminations there is sharp increase in the photocurrent. As a consequence, the maximum photocurrent $\left(i_{\max }\right)$ increase with increase in diffusion length because path for photochemical reaction was increased, but this is not observed experimentally. Whereas equilibrium photocurrent $\left(i_{\text {eq }}\right)$ decreased linearly. Therefore, it may be concluded that the main electroactive species are the leuco or semi form of dye (photosensitizer) in the illuminated and dark chamber respectively. The reductant and its oxidation product act only as electron carriers in the path. The results are summarized in Table 3.

The effect of electrode area on the current parameters of the cell was also studied. It was observed that with the increase in the electrode area the value of maximum photocurrent $\left(i_{\max }\right)$ is found to increase. The results are summarized in Table 4.

\subsection{Effect of Light Intensity}

The intensity of light was also affects the electrical output of the cell. It was observed that photocurrent shows a linear increasing behavior with the increase in light intensity whereas photopotential increased in logarithmic

Table 3. Effect of diffusion length.

\begin{tabular}{cccc}
\hline $\begin{array}{c}\text { Diffusion } \\
\text { length } \mathrm{D}_{\mathrm{L}} \\
(\mathrm{mm})\end{array}$ & $\begin{array}{c}\text { Maximum } \\
\text { photocurrent } \\
i_{\max }(\mu \mathrm{A})\end{array}$ & $\begin{array}{c}\text { Equilibrium } \\
\text { photocurrent } \\
i_{\mathrm{eq}}(\mu \mathrm{A})\end{array}$ & $\begin{array}{c}\text { Rate of initial } \\
\text { generation of } \\
\text { current }\left(\mu \mathrm{A} \text { min }^{-1}\right)\end{array}$ \\
\hline 35.0 & 434.0 & 380.0 & 15.50 \\
40.0 & 439.0 & 377.0 & 15.68 \\
45.0 & 445.0 & 375.0 & 15.89 \\
50.0 & 452.0 & 372.0 & 16.14 \\
55.0 & 460.0 & 368.0 & 16.43 \\
\hline
\end{tabular}

[Lissamine green B] $=2.8 \times 10^{-5} \mathrm{M}$; Light Intensity $=10.4 \mathrm{~mW} \cdot \mathrm{cm}^{-2}$; [Ascorbic acid] $=1.4 \times 10^{-3} \mathrm{M} ;$ Temperature $=303 \mathrm{~K}$; $[\mathrm{NaLS}]$ $=1.6 \times 10^{-3} \mathrm{M} ; \mathrm{pH}=12.58$.

Table 4. Effect of electrode area.

\begin{tabular}{ccc}
\hline $\begin{array}{c}\text { Electrode Area } \\
\left(\mathrm{cm}^{2}\right)\end{array}$ & $\begin{array}{c}\text { Maximum } \\
\text { photocurrent } i_{\max }(\mu \mathrm{A})\end{array}$ & $\begin{array}{c}\text { Equilibrium } \\
\text { photocurrent } i_{\mathrm{eq}}(\mu \mathrm{A})\end{array}$ \\
\hline 0.70 & 428.0 & 383.0 \\
0.85 & 436.0 & 379.0 \\
1.00 & 445.0 & 375.0 \\
1.15 & 454.0 & 372.0 \\
1.30 & 462.0 & 368.0 \\
\hline
\end{tabular}

[Lissamine green B] $=2.8 \times 10^{-5} \mathrm{M}$; Light Intensity $=10.4 \mathrm{~mW} \cdot \mathrm{cm}^{-2}$;

[Ascorbic acid] $=1.4 \times 10^{-3} \mathrm{M} ;$ Temperature $=303 \mathrm{~K} ; \quad[\mathrm{NaLS}$ ] $=1.6 \times 10^{-3} \mathrm{M} ; \mathrm{pH}=12.58$. manner. This increasing behavior of electrical output due to increase in number of photons with increase in light intensity. The effect of variation of light intensity on the photocurrent is graphically represented in Figure 3.

\section{6. i-V Characteristics}

The open circuit voltage $\left(V_{o c}\right)$ and short circuit current $\left(i_{s c}\right)$ of the photogalvanic cell were measured under the continuous illumination of light, with the help of digital $\mathrm{pH}$ meter (keeping the circuit open) and a microammeter (keeping the circuit closed) respectively. The potential and current in between these two extreme values $\left(V_{p p}\right.$ and $i_{p p}$ ) were recorded with the help of a carbon pot $(\log 407 \mathrm{~K})$ connected in the circuit of microammeter through which an external load applied. i- $\mathrm{V}$ characteristics of the cell containing Lissamine green B-Ascorbic acid-NaLS system is shown in current-potential curve (Figure 4). It was observed that $\mathrm{i}-\mathrm{V}$ curve deviated from its regular rectangular shape. A point in the $\mathrm{i}-\mathrm{V}$ curve,

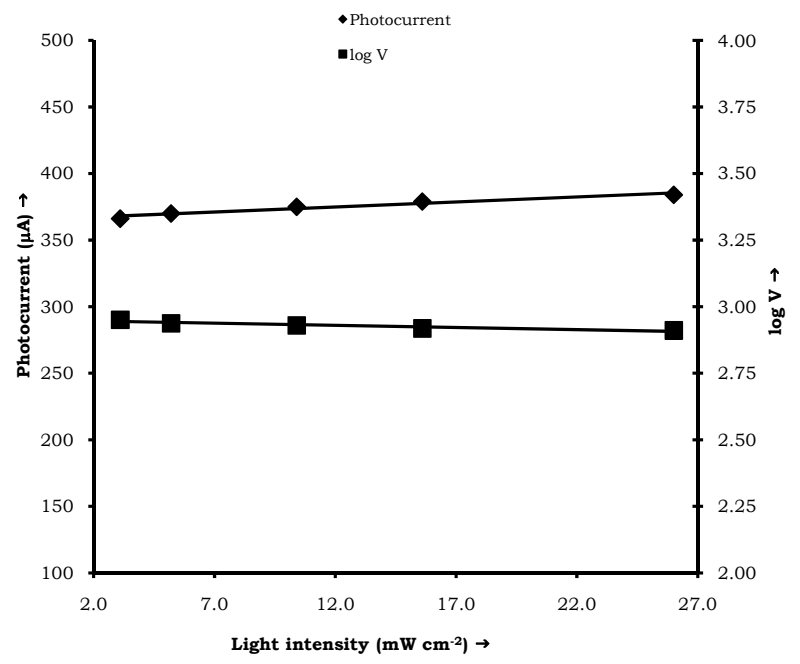

Figure 3. Variation of photocurrent and $\log \mathrm{V}$ with light intensity.

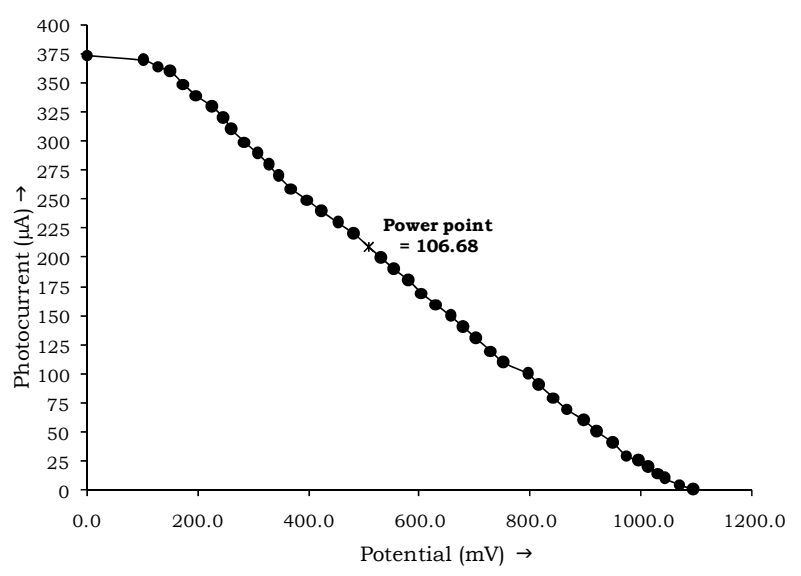

Figure 4. Current-potential curve. 
called power point (pp), was determined where the product of curve of current and potential was maximum. With the help of $\mathrm{i}-\mathrm{V}$ curve, the fill-factor was calculated as 0.2598 using the formula:

$$
\text { Fill factor }(\eta)=\frac{V_{p p} \times i_{p p}}{V_{o c} \times i_{s c}}
$$

\subsection{Cell Performance and Conversion Efficiency}

The performance of the photogalvanic cell was observed by applying an external load (necessary to have current at power point) after termination the illumination as soon as the potential reaches a constant value. The performance was determined in terms of $t_{1 / 2}$, i.e., the time required in fall of the output (power) to its half at power point in dark. It was observed that the cell can be used in dark for 170.0 minutes. Performance of the cell is graphically shown in time-power curve (Figure 5).

Conversion efficiency of the cell was determined as $1.0257 \%$ using the formula:

$$
\text { Conversion efficiency }=\frac{V_{p p} \times i_{p p}}{A \times 10.4 \mathrm{~mW} \cdot \mathrm{cm}^{-2}} \times 100 \%
$$

\section{Mechanism}

Light energy is converted in to chemical energy by driving a suitable redox reaction against the potential gradient. The thionine-Fe (II) aqueous photogalvanic system was studies by Jana [19]. Reactions are as follow:

$$
\begin{aligned}
& \mathrm{TH}^{+} \stackrel{h v}{\longrightarrow}{ }^{1} \mathrm{TH}^{+} \rightarrow{ }^{3} \mathrm{TH}^{+} \\
& { }^{3} \mathrm{TH}^{+}+\mathrm{H}^{+} \rightarrow \mathrm{TH}^{+}\left(I_{S C} \text { to ground state }\right) \\
& { }^{3} \mathrm{TH}_{2}^{2+}+\mathrm{Fe}^{2+} \rightarrow{ }^{*} \mathrm{TH}_{2}^{+}+\mathrm{Fe}^{3+} \\
& (\text { Semi - thionine radical formation }) \\
& { }^{*} \mathrm{TH}_{2}^{+}+\mathrm{Fe}^{3+} \rightarrow \mathrm{TH}^{+}+\mathrm{Fe}^{2+}+\mathrm{H}^{+}
\end{aligned}
$$

(Back thermal reaction)$$
{ }^{*} \mathrm{TH}^{2+}+\mathrm{TH}^{2+} \rightleftharpoons \mathrm{TH}^{+}+\mathrm{TH}^{3+}
$$

(Dispropotionation reaction)

$$
{ }^{*} \mathrm{TH}^{2+} \rightarrow \mathrm{TH}^{+}+\mathrm{H}^{+}+e^{-}
$$

(Anode Reaction at illuminated electrode)

$$
\mathrm{Fe}^{3+}+e^{-} \rightarrow \mathrm{Fe}^{2+} \text { (Dark electrode) }
$$

where $\mathrm{TH}^{+}$was represented dark thione is the oxidized form.

On the basis of above, the tentative reaction mechanism in our system proposed as:

Illuminated chamber: On irradiation, dye molecules get excited. The excited dye molecules accept an electron from reductant and converted into semi or leuco form of dye, and the reductant into its excited form. At platinum electrode the semi or leuco form of dye loses an electron and gets converted into original dye molecule.

Dark chamber: At calomel electrode dye molecule accepts an electron from electrode and gets converted into semi or leuco form. Finally leuco/semi form of dye and oxidized form of reductant combine to give original dye and reductant molecule. This cycle of mechanism is repeated again and again leading production of current continuously. Scheme of mechanism proposed by Genwa and Sagar [20] and is shown in Figure 6.

\section{Conclusion}

Various forms of solar cells like photoelectrochemical, photovoltaic and photogalvanic cells are studied for harvesting solar energy. Photovoltaic cells are widely used in most countries for conversion and storage of solar energy but owing to their low storage capacity, photogalvanic cells are preferred because they have the added advantage of inherent storage capacity. The use of pho togalvanic cell Lissamine green B-Ascorbic acid-NaLS

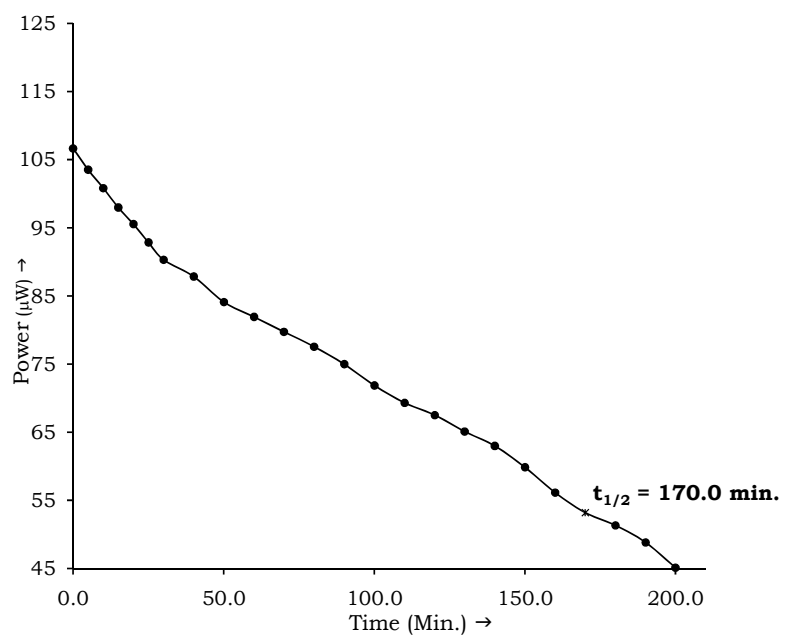

Figure 5. Time-power curve.

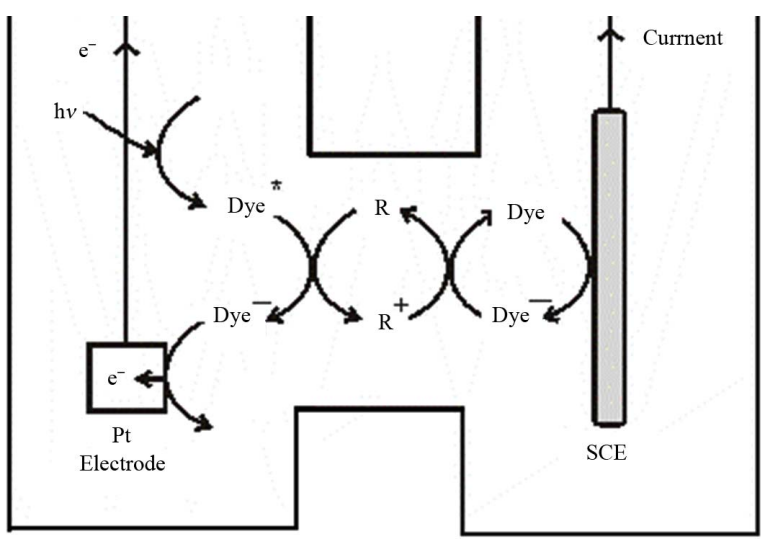

Figure 6. Scheme of mechanism. 
system not only enhances the electrical output of the cell but also increases the conversion efficiency and storage capacity in comparison to the photogalvanic cell using single photosensitizer. Efforts will be made in future to make it more efficient.

\section{Acknowledgements}

The authors are thankful to Head, Department of Chemistry for providing necessary facilities and Dr. P. Koli for critical discussion and suggestions.

\section{REFERENCES}

[1] W. Hafele, "Energy in a Finite World: A Global Systems Analysis," Ballinger Publishing Company, Pensacola, 1981.

[2] E. Becquerel, "On Electron Effects under the Influence of Solar Radiation," Comptes Rendus de 'l' Academie Sciences Paris, Vol. 9, 1839, p. 561.

[3] E. K. Rideal and E. G. Williams, "The Action of Light on the Ferrous Iodine Iodide Equilibrium," Journal of the Chemical Society, Vol. 127, 1925, pp. 258-269. doi: $10.1039 /$ ct9252700258

[4] E. Rabinowitch, "The Photogalvanic Effect I: The Photochemical Properties of the Thionine-Iron System," Journal of Chemical Physics, Vol. 8, No. 7, 1940, pp. 551559. doi:10.1063/1.1750711

[5] E. Rabinowitch, "The Photogalvanic Effect II: The Photogalvanic Properties of Thionine-Iron System," Journal of Chemical Physics, Vol. 8, No. 7, 1940, pp. 560-566. doi:10.1063/1.1750712

[6] M. A. Fox and Kabir-ud-din, "A New Carbanionic Photogalvanic Cell," Journal of Physical Chemistry, Vol. 83, No. 13, 1979, pp. 1800-1801. doi:10.1021/j100476a022

[7] A. S. N. Murthy, A. C. Dak and K. S. Reddy, "Photogalvanic Effect in Riboflavin Ethylenediaminetetraacetic Acid System," International Journal of Energy Research, Vol. 4 No. 4, 1980, pp. 339-343. doi:10.1002/er.4440040405

[8] K. K. Rohatgi-Mukherjee, M. Roy and B. B. Bhowmik, "Photovoltage Generation of the Phenosafranine DyeEDTA Sandwich Cell," Solar Energy, Vol. 31, 1983, pp. 417-418. doi:10.1016/0038-092X(83)90142-1

[9] S. C. Ameta, S. Khamesra, M. Bala and K. M. Gangotri, "Use of Micelles in Photogalvanic Cell for Solar Energy Conversion and Storage," Philippine Journal of Science, Vol. 119, No. 4, 1990, pp. 371-373.

[10] K. M. Gangotri, P. Kalla, K. R Genwa, O. P. Regar, C. Lal and R. Meena, "Use of Tween-80 in Photogalvanic
Cell for Solar Energy Conversion and Storage: Toludine Blue-Glucose System," Indian Council of Chemists, Vol. X, No. 2, 1994, p. 20.

[11] K. M. Gangotri, P. Kalla, K. R. Genwa, O. P. Regar, C. Lal and R. Meena, "Photogalvanic Cells as a Device for Solar Energy Conversion and Storage," Asian Journal of Chemistry, Vol. 5, No. 1, 1994, p. 69.

[12] K. M Gangotri and C. Lal, "Studies in Photogalvanic Effect and Mixed Dyes System: EDTA-Methylene BlueToludine Blue System," International Journal of Energy Research, Vol. 24, No. 4, 2000, pp. 365-371. doi:10.1002/(SICI)1099-114X(20000325)24:4<365::AID -ER593>3.0.CO;2-I

[13] K. M. Gangotri and C. Lal, "Use of Mixed Dyes in Photogalvanic Cell for Solar Energy Conversion and Storage: EDTA Methylene Blue and Azur-B System," Energy Sources Part A, Vol. 23, No. 3, 2001, pp. 267-273. doi:10.1080/00908310151133988

[14] K. R. Genwa and K. M. Gangotri, "Use Of Tween-80 in Photogalvanic Cells for Solar Energy Conversion and Storage: Nitrilotriacetic Acid-Azur B System," Afinidad, Vol. 492, 2001, p. 147.

[15] K. M. Gangotri and R. C. Meena, "Use of Reductant and Photosensitizer in Photogalvanic Cell for Solar Energy Conversion and Storage: Oxalic Acid-Methyline Blue System," Journal of Photochemistry and Photobiology A: Chemistry, Vol. 141, No. 2, 2001, pp. 175-177. doi:10.1016/S1010-6030(01)00416-6

[16] K. R. Genwa and K. M. Gangotri, "Studies on Photogalvanic Cell Containing Azur B-NTA-CPC System," Indian Council of Chemists, Vol. 21, No. 1, 2004, pp. 21-25.

[17] K. R. Genwa and A. Kumar, "Role of Rhodamine B in Photovoltage Generation Using Anionic Surfactant in Liquid Phase Photoelectrochemical Cell for Solar Energy Conversion and Storage," Journal of the Indian Chemical Society, Vol. 87, No. 8, 2010, pp. 933-939.

[18] K. R. Genwa and A. Chouhan, "Optimum Efficiency of Photogalvanic Cell for Solar Energy Conversion and Storage Containing Brilliant Black PN-Ammonium Lauryl Sulphate-EDTA System," Research Journal of Recent Sciences, Vol. 1, 2012, pp. 117-121.

[19] A. K. Jana, "Solar Cells Based on Dyes," Journal of Photochemistry and Photobiology A: Chemistry, Vol. 132, No. 1, 2000, pp. 1-17. doi:10.1016/S1010-6030(99)00251-8

[20] K. R. Genwa and C. P. Sagar, "Role of Carmine in Tween 80-Ascorbic Acid System for Energy Conversion," Research Journal of Recent Sciences, Vol. 1, 2012, pp. 6266. 